\title{
PENERAPAN PENDEKATAN READER RESPONS DALAM MENINGKATKAN KEMAMPUAN MEMBACA NOVEL SISWA SMP MUTIARA SINGARAJA
}

\author{
Ngurah Harsana ${ }^{1}$, I Made Astika² , I Nyoman Sudiana ${ }^{3}$ \\ Jurusan Pendidikan Bahasa dan Sastra Indonesia, Fakultas Bahasa dan Seni \\ Universitas Pendidikan Ganesha \\ Singaraja, Indonesia \\ e-mail: ngurahharsana1@gmail.com, tulanggadang@yahoo.com, \\ sudiana195723@gmail.com
}

\begin{abstract}
ABSTRAK
Penelitian tindakan kelas yang dilakukan di SMP Mutiara Singaraja ini bertujuan (1) mengidentifikasi langkah-langkah penerapan pendekatan reader respons dalam meningkatkan kemampuan membaca novel siswa SMP Mutiara Singaraja, (2) mengetahui peningkatan kemampuan membaca novel siswa dengan menggunakan pendekatan reader respons di SMP Mutiara Singaraja, dan (3) mengetahui respons siswa terhadap penerapan pendekatan reader respons dalam pembelajaran memahami buku novel. Penelitian ini dilaksanakan dengan dua siklus dan menggunakan lima tahap penelitian tindakan kelas, yakni (1) refleksi awal, (2) perencanaan tindakan, (3) pelaksanaan, (4) observasi dan evaluasi, dan (5) refleksi. Data dikumpulkan dengan metode observasi, tes, angket/kuisioner, serta wawancara dan dianalisis secara deskriptif kuantitatif dan kualitatif. Hasil penelitian menunjukkan nilai rata-rata siklus I adalah 69,05 atau mengalami peningkatan $8,35 \%$ dari nilai sebelumnya 60,70 . Nilai rata-rata siklus II adalah 79,85 atau meningkat sebesar $10,8 \%$ dari siklus I dan meningkat $19,15 \%$ dari nilai rata-rata prasiklus. Perolehan rata-rata respons siswa pada siklus I sebesar 43,05 dalam kategori positif dan pada siklus II mengalami peningkatan sebesar 1,6\%, sehingga menjadi 44,65 dalam kategori positif.
\end{abstract}

Kata-kata kunci: reader respons, membaca, novel.

\begin{abstract}
The classroom action research conducted at SMP Mutiara Singaraja aimed to (1) identify the steps of applying reader response approach in improving students 'novel reading ability at SMP Mutiara Singaraja, (2) know the improvement of students' novel reading skill by using response reader approach at SMP Mutiara Singaraja , and (3) know the students' response toward the applied reader response approach in learning to understand novel. The study was conducted in two cycles and used five stages of classroom action research, namely (1) first reflection, (2) action planning, (3) implementation, (4) observation and evaluation, and (5) reflection. Data was collected by using observation method, test, questionnaire / questionnaire, and interview then analyzed descriptive quantitatively and qualitatively. The results showed the average value of cycle I was 69.05 or increased by $8.35 \%$ from the previous value 60.70 . The average value of cycle II was 79.85 or increased by $10.8 \%$ from cycle I and increased $19.15 \%$ from the average value of pre-cycle. The average of the achievement of student response in the first cycle is 43.05 in positive category and in cycle II had increased by $1.6 \%$, thus increased by 44.65 in the positive category.
\end{abstract}

Keywords: reader response, reading, novel. 


\section{PENDAHULUAN}

Sastra merupakan salah satu seni yang mengkaji tentang bagaimana dunia realita yang sebenarnya. Melalui sastra, pembaca akan lebih memiliki wawasan yang luas terhadap kenyataan. Dalam dunia sastra dikenal adanya sastra lisan dan tulisan. Sastra lisan merupakan sebuah karya sastra yang disampaikan dalam bentuk tuturan, sedangkan sastra tulisan merupakan sebuah bentuk karya sastra yang dibuat dalam bentuk tulisan.

Hardjaja (1991) menyatakan bahwa karya sastra sudah diciptakan orang jauh sebelum memikirkan apa hakikat sastra dan apa nilai dan maknanya. Karya sastra merupakan sebuah jalan yang dapat ditempuh oleh setiap pembaca untuk mengetahui kehidupan sebenarnya.

Sehubungan dengan hal itu, Astika dan Yasa (2014) menyatakan bahwa karya sastra bukanlah suatu karangan kosong atau khayalan yang sifatnya tidak sekadar menghibur pembaca saja tetapi melalui karya sastra pembaca lebih memahami masalah kehidupan.Oleh karena itu, karya sastra perlu diketahui oleh setiap kalangan.

Sastra erat hubungannya dengan keterampilan berbahasa. Salah satu keterampilan berbahasa yang dapat digunakan untuk memahami sastra adalah keterampilan membaca.

Tarigan (1979) menyatakan membaca merupakan suatu proses yang dilakukan serta dipergunakan oleh pembaca untuk memeroleh pesan yang hendak disampaikan oleh penulis melalui media kata-kata atau bahasa tulisan. Berdasarkan urutannya sebagai salah satu aspek keterampilan berbahasa, keterampilan membaca merupakan keterampilan yang sangat penting dimiliki. Hal tersebut dikarenakan, dalam proses membaca, pembaca dapat memeroleh sebuahpemahaman terkait isi yang disampaikan dalam bahan bacaan. Di samping itu, Sudiana (2007) mengatakan bahwa membaca merupakan aktivitas yang sangat kompleks yang melibatkan faktor fisik dan mental. Dengan kata lain, membaca bukanlah hal yang semestinya sulit dilakukan oleh seorang siswa karena fisik dan mental sudah dimiliki. Hanya saja kedua faktor tersebut perlu dibina dan diarahkan sesuai dengan jalurnya.

Sehubungan dengan hal itu, Yamin (2014) mengatakan bahwa membaca adalah upaya yang dilakukan seseorang untuk mendapat pemahaman baru. Pemahaman yang dimaksud dalam pernyataan tersebut adalah ketika pembaca menemukan pemecahan masalah, mendadapat keyakinan yang lebih kuat, dan memeroleh pengetahuan yang lebih luas.

Keterampilan membaca merupakan keterampilan dasar yang harus dikuasai oleh seorang pelajar untuk mengikuti kegiatan belajar mengajar. Sujanto (1988) menyatakan bahwa kegiatan membaca sebagai salah satu kegiatan menyimak, tidak lain adalah juga merupakan kegiatan komunikasi, karena membaca tidak lain adalah menerima pesan dari buku-buku.

Mengingat bahwa sastra sangatlah penting untuk dipahami, tentu kemampuan membaca juga perlu menjadi sorotan bagi seorang pelajar seperti SMP. Tanpa membaca siswa tidak dapat memahami sebuah sastra. Dalam hal ini juga untuk bisa memahami bacaan, pembaca dituntut untuk menggunakan kemampuan kognitif dan bahasanya ketika memproses bacaan yang memilki struktur organisasi yang spesifik.

Novel merupakan sebuah karya sastra imajinatif. Imajinatif yang dimaksud adalah berupa khayalan atau imajinasi yang dituangkan oleh pengarang. Novel merupakan bentuk sastra baru yang muncul kemudian dari sastra lainnya seperti puisi dan drama.

Priyatni (2012) menyatakan bahwa novel merupakan bentuk prosa yang agak panjang dan meninjau kehidupan seharihari. Pada dasarnya memang benar jika novel lebih banyak menceritakan suatu kisah yang tidak terlepas dari kejadian yang sering dialami dalam kehidupan sehari-hari.

Membaca novel sangatlah perlu dilakukan bagi setiap kalangan karena dapat memeroleh wawasan lebih luas tentang kehidupan. Akan tetapi, genre yang 
dipilih juga harus menyesuaikan dengan tingkat intelektual yang dimilki pembacanya.

Berdasarkan pengalaman penulis selama melakukan PPL-Real di SMP Mutiara Singaraja, penulis menemukan suatu permasalahan yang dialami oleh siswa saat mengikuti pembelajaran Bahasa Indonesia dengan materi memahami teks sastra. Masalah yang sering dihadapi siswa dalam pembelajaran ini yakni kesulitan dalam memahami sebuah bacaan seperti novel.

Dilihat dari hasil observasi awal, masalah di atas ditemukan di kelas VIII B SMP Mutiara Singaraja. Penulis memeroleh informasi bahwa kemampuan membaca siswa dalam memahami novel masih rendah. Hal ini terbukti dari skor rata-rata yang diperoleh siswa sebesar 60,70, sedangkan ketuntasan hasil belajar yang harus dicapai rata-rata minimal 75 . Kurangnya keberhasilan siswa dalam belajar bahasa Indonesia dengan rincian materi memahami novel remaja disebabkan oleh beberapa faktor, yaitu (1) minat dan motivasi siswa dalam belajar masih rendah, (2) rendahnya tingkat pemahaman siswa terhadap teks sastra novel (3) sifat malas siswa yang tinggi dalam kegiatan membaca, (4) kurangnya kebiasaan membaca siswa.

Alasan mendasar penelitian ini dilakukan di kelas VIII B SMP Mutiara Singaraja, karena sesuai dengan kurikulum yang ditetapkan, yaitu KTSP yang dalam silabusnya telah tercantum materi pembelajaran membaca dengan rincian yang berbunyi "memahami buku novel remaja (asli atau terjemahan)". Dalam hal ini, siswa dituntut untuk mampu memahami isi bacaan sebuah novel remaja.

Melihat berbagai permasalahan tersebut, penulis mencoba memberikan solusi kepada guru agar kemampuan membaca siswa dalam memahami buku novel dan kebiasaan malas siswa yang merajalela bisa teratasi dengan menerapkan pendekatan reader respons dalam pemebelajaran memahami teks sastra novel.

Berdasarkan paparan tersebut, dalam penelitian ini mencoba memberikan suatu pendekatan yang tepat digunakan untuk meningkatkan kemampuan membaca siswa khususnya teks sastra berupa novel di kelas VIII B SMP Mutiara Singaraja. Seperti yang telah dijelaskan di atas, apabila pemahaman siswa meningkat, maka minat baca pun muncul. Jika minat tersebut muncul, tentu kebiasan membaca akan tumbuh dan kebiasaan malas siswa juga terminimalisir. Alasan dipilinnya teks sastra seperti novel juga dikarenakan siswa masih kesulitan dalam menemukan nilai-nilai estetik novel yang menjadi pusat pemahaman siswa dalam membaca.

Ratna (2004) menyatakan bahwa dalam pendekatan terkandung manfaat penelitian yang diharapkan, baik secara teoretis maupun praktis, baik terhadap peneliti secara individu maupun masyarakat pada umumnya. Pendekatan reader respons merupakan sebuah pendekatan yang lebih menitikberatkan bagaimana timbulnya sebuah komunikasi antara pembaca dan teks.

Sejalan dengan pernyataan tersebut, pendekatan ini juga bertujuan untuk meningkatkan keterampilan pembacanya dalam bergaul dengan sastra (Sarumpaet, 2010). Pendekatan ini tidak hanya melibatkan guru, tetapi juga melibatkan siswa sebagai pembaca. Mengingat bahwa memahami sastra sangatlah penting bagi siswa, pendekatan reader respons dirasa sangat tepat digunakan untuk meningkatkan pemahaman siswa terhadap bacaan sastra seperti novel.

Hubungan antara pendekatan reader respons dengan pemahaman siswa dapat diketahui melalui reaksi yang muncul dengan menerapkan pendekatan ini. Siswa sebagai seorang pembaca lebih mudah memahami bacaan khususnya bacaan sastra novel apabila siswa itu sendiri mampu memunculkan sebuah reaksi terhadap teks bacaannya.

Keunggulan yang dimiliki dalam pendekatan reader respons, yaitu mampu menciptakan adanya reaksi antara pembaca dengan teks sastra, membuat pembacanya untuk mendalami bacaan dengan mengikutsertakan emosi, dan mampu untuk memberikan penilaian berupa makna terhadap teks sastra yang dibaca. 
Penelitian ini tentu sangat penting dilakukaan guna memperbaiki masalah yang ditemukan di SMP Mutiara Singaraja. Tanpa adanya penelitian ini, kemampuan siswa di SMP Mutiara Singaraja dalam memahami teks sastra novel tetap rendah dan tidak ada perubahan untuk menjadi lebih baik.

Keberhasilan penerapan pendekatan ini telah ditemukan oleh peneliti, seperti penelitian yang dilakukan oleh Susilo dan Aan Anisa (2017) yang melakukan penelitian dengan judul "Penerapan Model Respon Pembaca dalam Pembelajaran Apresiasi Cerpen di SMA".

Persamaan yang dimiliki penelitian tersebut adalah sama-sama menggunakan pendekatan reader respons dalam melaksanakan penelitian, sedangkan perbedaannya terdapat pada tujuan yang ingin diperoleh. Perbedaan lainnya juga terdapat pada rancangan penelitian yang digunakan. Penelitian di atas menggunakan rancangan penelitian deskriftif kualitatif, sedangkan penelitian ini menggunakan rancangan penelitian tindakan kelas (PTK).

Selain itu, terdapat juga penelitian yang dilakukan oleh Inderawati (2009) yang melakukan penelitian dengan judul "Model Pembelajaran Berbasis Respons Pembaca dan Simbol Visual untuk Mengembangkan Apresiasi Sastra dan Kemampuan Berbahasa Inggris Mahasiswa".

Persamaan yang dimiliki penelitian tersebut masih sama-sama menggunakan pendekatan reader respons dalam melaksanakan penelitian, sedangkan perbedaannya terdapat pada tujuan yang ingin diperoleh. Perbedaan lainnya juga terdapat pada objek penelitian yang ditentukan. Penelitian di atas menggunakan mahasiswa sebagai objek, sedangkan penelitian ini menggunakan siswa dan guru sebagai objek penelitian.

Melihat penerapan pendekatan reader respons belum banyak yang melakukan, tentu penelitian ini sangat perlu untuk diterapkan. Di samping itu, dengan menerapkan pendekatan ini, juga memberikan kesempatan kepada siswa berimajinasi dan aktif untuk belajar memahami teks sastra seperti novel di dalam kelas.
Berdasarkan latar belakang di atas, peneliti melakukan sebuah penelitian dengan judul "Penerapan Pendekatan Reader Respons dalam Meningkatkan Keampuan Membaca Novel Siswa SMP Mutiara Singaraja".

Dilihat dari masalah di atas, penelitian ini membahas tentang, (1) langkah-langkah penerapan pendekatan reader respons dalam meningkatkan kemampuan membaca novel siswa SMP Mutiara Singaraja, (2) peningkatan kemampuan membaca novel siswa dengan menggunakan pendekatan reader respons di SMP Mutiara Singaraja, dan (3) respons siswa terhadap penerapan pendekatan reader respons dalam pembelajaran memahami novel remaja.

Sejalan dengan rumusan masalah yang telah diuraikan di atas, tujuan penelitian ini adalah untuk mengidentifikasi langkah-lagkah penerapan pendekatan reader respons dalam meningkatkan kemampuan membaca novel siswa SMP Mutiara Singaraja, mengetahui peningkatan kemampuan membaca novel siswa dengan menggunakan pendekatan reader respons di SMP Mutiara Singaraja, dan untuk mengetahui respons siswa terhadap penerapan pendekatan reader respons dalam pembelajaran memahami novel remaja. Hasil dari penelitian ini diharapkan memberikan manfaat bagi siswa, guru, sekolah, dan peneliti lainnya.

\section{METODE PENELITIAN}

Penelitian ini menggunakan rancangan penelitian tindakan kelas. Penelitian tindakan kelas ini dilaksanakan di SMP Mutiara Singaraja. Subjek dalam penelitian ini adalah guru mata pelajaran bahasa Indonesia di kelas VIII B yang bernama Dra. Ni Luh Putu Arthini dan siswa kelas VIII B SMP Mutiara Singaraja. Siswa kelas VIII dipilih sebagai subjek penelitian karena kemampuan membaca siswa dalam memahami novel remaja masih kurang dan hal tersebut dibuktikan melaluiskor yang diperoleh siswa masih di bawah KKM, yaitu 75.

Objek penelitian merupakan hal yang dikaji dalam penelitian tersebut. Objek 
dalam penelitian ini adalah penerapan pendekatan reader respons dalam meningkatkan kemampuan membaca novel siswa kelas VIII B dan respons siswa terhadap pembelajaran.

Pelaksanaan penelitian tindakan kelas (PTK) dilakukan secara bertahap dan multisiklus. Hal ini dilakukan untuk mendapatkan hasil terbaik memeroleh data yang valid. Setiap siklus terdiri atas refleksi awal, dilanjutkan dengan rencana tindakan, pelaksanaan tindakan, observasi/ evaluasi, dan refleksi. Prosedur ini dimulai dari analisis masalah. Setelah menemukan kemudian dilakukan refleksi awal. Refleksi awal dilakukan untuk mengidentifikasi masalah yang dihadapi guru maupun siswa dalam pembelajaran. Sebelum tindakan dilakukan, membuat suatu perencanaan pembelajaran sangat diperlukan. Perencanaan tersebut menjadi pedoman dalam melaksanakan tindakan. Setelah membuat perencanaan dilanjutkan dengan pelaksanaan tindakan. Pelaksanaan tindakan harus disesuaikan dengan perencanaan yang telah dibuat.

Setelah pelaksanaan tindakan, dilakukan observasi untuk mengetahui pemantauan terhadap berlangsungnya siklus. Refleksi digunakan untuk tindakan selanjutnya, yang bertujuan memformulasikan kekuatan-kekuatan, kelemahan-kelemahan, dan hambatanhambatan yang ditemukan dan dianggap mengganjal dalam upaya pencapaian keberhasilan optimal. Prosedur ini dilakukan berulang-ulang sampai data yang di dapat menunjukkan hasil terbaik atau telah memenuhi kriteria keberhasilan yang telah ditentukan.

Metode pengumpulan data merupakan langkah paling utama dalam penelitian karena tujuan utama dari penelitian adalah memeroleh data yang memenuhi standar data yang ditetapkan. Dalam pengumpulan data penelitian, peneliti menggunakan beberapa metode pengumpulan data.

Pertama, untuk mengetahui langkahlangkah penerapan pendekatan reader respons dalam pembelajaran, peneliti menggunakan metode observasi sebagai penilaian proses. Kedua, untuk mengetahui peningkatan kemampuan membaca novel siswa, peneliti menggunakan metode tes sebagai penilaian hasil. Ketiga,untuk mengetahui respons siswa, peneliti menggunakan metode angket/ kuesioner dan wawancara.

Penelitian ini menggunakan instrumen pokok, yaitu instrumen tes dan instrumen nontes. Instrumen yang berupa tes digunakan untuk mengukur tingkat kemampuan membaca siswa. Instrumen tes berupa soal esai yang harus dikerjakan oleh siswa setelah menerapkan pendekatan reader respons dalam proses membaca. Sedangkan instrumen nontes berupa lembar observasi, kuesioner dan wawancara.

Dalam penelitian tindakan kelas ini, peneliti menggunakan teknik analisis data deskriptif kuantitatif dan deskriptif kualitatif. Berdasarkan ketiga jenis data yang diperoleh, langkah-langkah penerapan pendekatan reader respons dalam meningkatkan kemampuan membaca novel siswa dianalisis dengan teknik analisis data deskriptif kualitatif, hasil kemampuan membaca siswa dalam memahami novel remaja dianalisis dengan deskriptif kuantitatif dan kualitatif, dan respons siswa dianalisis dengan deskriptif kuantitatif dan kualitatif.

Analisis data hasil belajar dilakukan untuk kedua siklus, yaitu siklus I dan siklus II dengan tujuan mengukur hasil kemampuan membaca novel siswa dengan menerapkan pendekatan reader respons. Hasil tes pada siklus I dianalisis, dilanjutkan dengan mencari kesulitan-kesulitan yang dialami siswa selama proses pembelajaran. Pada siklus II diharapkan siswa mendapatkan hasil yang baik.

Kriteria keberhasilan penelitian adalah kemampuan membaca siswa dikatakan berhasil apabila $75 \%$ dari keseluruhan siswa memeroleh nilai 75 ke atas atau melebihi KKM, sedangkan untuk respon, penerapan pendekatan reader respons dapat dikatakan diterima dengan baik oleh siswa apabila $75 \%$ siswa memberikan respons positif. 


\section{HASIL PENELITIAN DAN PEMBAHASAN Hasil Penelitian}

Setelah dilakukan penelitian mengenai penerapan pendekatan reader respons dalam meningkatkan kemampuan membaca novel siswa kelas VIII B SMP Mutiara Singaraja, dapat diketahui hasil penelitian sebagai berikut.

Berdasarkan hasil observasi yang dilakukan, dapat dikatakan bahwa langkahlangkah pelaksanaan pembelajaran yang dilakukan sudah tergolong baik/bagus. Hal ini dapat dilihat dari penilaian yang diberikan peneliti atau observer saat mengamati guru mengajar.

Pada tindakan siklus I yang dilaksanakan dalam dua kali pertemuan, dari 20 aspek yang harus dilakukan guru, hanya 3 (tiga) aspek yang tidak terlaksana berdasarkan rencana yang telah disusun sebelumnya. Ketiga aspek tersebut, yaitu (1) guru tidak mengecek kesiapan siswa. (2) guru tidak menyimpulkan dan memberikan umpan balik atau penguatan terhadap unjuk kerja siswa. (3) guru tidak melakukan refleksi dengan menanyakan ke siswa hambatan yang dihadapi dalam menyampaikan hal-hal yang menarik dari novel.

Hasil tes kemampuan membaca novel siswa pada siklus I, dapat dilihat dalam tabel sebagai berikut.

Tabel 1.1 Hasil Tes Kemampuan Membaca Novel Siswa Pada Siklus I

\begin{tabular}{|c|c|c|c|c|}
\hline No & Kat. & S. & F. & $\%$ \\
\hline 1. & SB & $85-100$ & 1 & 5 \\
\hline 2. & B & $70-84$ & 8 & 40 \\
\hline 3. & C & $60-69$ & 7 & 35 \\
\hline 4. & K & $50-59$ & 4 & 20 \\
\hline 5. & SK & $<50$ & 0 & 0 \\
\hline & Jml. & & 20 & 100 \\
\hline
\end{tabular}

Keterangan.

Kat: kategori S. : skor F. : Frekuensi

SB : sangat baik

B : baik

C : cukup

$\mathrm{K}$ : kurang

SK : sangat kurang
Berdasarkan tabel hasil keseluruhan pada siklus I, diperoleh rata-rata 69,05 yang secara klasikal berkategori cukup.

Berdasarkan tabel di atas dapat diketahui bahwa kemampuan siswa kelas VIII B SMP Mutiara setelah mendapatkan tindakan dari 20 orang siswa, terdapat 1 orang siswa atau $5 \%$ memperoleh kategori sangat baik, 8 orang siswa atau $40 \%$ memperoleh kategori baik, 7 orang siswa atau 35\% memperoleh kategori cukup dan 4 orang atau $20 \%$ siswa memeroleh kategori kurang.

Dengan nilai rata-rata sebesar 69,05 maka terjadi peningkatan nilai dari pratindakan sebesar $8,35 \%$. Jika dilihat dari nilai yang ditargetkan pada siklus I yaitu 75 , maka terdapat 11 orang siswa yang masih berada di bawah nilai rata-rata (nilai KKM). Oleh karena itu, dilanjutkan pada siklus II dengan harapan siswa mampu mencapai nilai 75 .

Berdasarkan hasil respons siswa pada siklus I, dapat dirinci dari 20 orang siswa yang telah mengisi angket, terdapat 12 orang siswa $(60 \%)$ yang memberikan respons sangat positif terhadap penerapan pendekatan reader respons untuk meningkatkan kemampuan membaca siswa dalam memahami novel 3600 Detik. Sisanya, terdapat 6 orang siswa (30\%) memberikan respons positif dan 2 orang siswa (10\%) memberikan respons cukup positif. Dari 20 orang siswa di kelas VIII B SMP Mutiara Singaraja, tidak ada siswa yang memberikan respons yang kurang positif ataupun sangat kurang positif. Secara keselutuhan, rata rata respons yang diperoleh dalam pelaksanaan siklus I, yaitu 43,05 (dalam kategori positif).

Berdasarkan hasil observasi yang peneliti lakukan selama tindakan pada siklus I, pelaksanaanpenelitian sudah berlangsung dengan baik. Pembelajaran memahami novel remaja dengan menerapkan pendekatan reader respons sudah berjalan dengan lancar dan sesuai dengan rencana.

Hambatan-hambatan yang ditemukan ketika observasi adalah berikut ini (a) sebagian besar siswa masih kurang berkonsentrasi saat mengikuti pembelajaran di kelas, (b) beberapa siswa 
belum mampu menangkap penjelasan yang diberikan oleh guru mengenai nilai-nilai yang terkandung dalam sebuah novel, (c) beberapa siswa tidak melakukan proses berfikir dengan baik selama mengikuti pembelajaran dengan menerapkan pendekatan reader respons., (d) siswa kurang disiplin dalam mengikuti proses belajar-mengajar.Rata-rata hasil tes kemampuan membaca siswa dalam memahami novel remaja dengan menerapkan pendekatan reader respons pada siklus I belum mencapai kriteria ketuntasan minimal, yakni hanya 75 sehingga tindakan dilanjutkan ke siklus II dengan perencanaan yang lebih matang agar hambatan-hambatan pada siklus I dapat diperbaiki pada siklus II.

Berikut hasil keseluruhan pada siklus II. Hasil observasi pada pelaksanaan pembelajaran pada siklus II, bahwa langkah-langkah kegiatan pembelajaran yang dilakukan oleh guru tergolong sangat baik. Hal itu dapat diamati dari penilaian yang diberikan oleh observer/peneliti saat mengamati guru. Pada siklus II yang dilaksanakan dua kali pertemuan, secara umum terdapat 20 aspek yang dilakukan oleh guru. Ternyata, semua aspek telah dilaksanakan dalam kegiatan pembelajaran dengan baik. Guru sudah melaksanakan kegiatan pembelajaran ini sesuai prosedur yang sudah direncanakan pada kegiatan refleksi siklus I. Pelaksanaan pembelajaran pada siklus II sudah dapat dikatakan lebih baik dari pelaksanaan pembelajaran siklus I.

Berdasarkan hasil tes pada siklus II kemampuan membaca novel siswa kelas VIII B SMP Mutiara Singaraja dapat dilihat dalam tabel berikut ini.

\section{Tabel 1.2 Hasil Tes Kemampuan} Membaca Novel Siswa Pada Siklus II

\begin{tabular}{|c|c|c|c|c|}
\hline No & Kat. & S. & F. & $\%$ \\
\hline 1. & SB & $85-100$ & 8 & 40 \\
\hline 2. & B & $70-84$ & 10 & 50 \\
\hline 3. & C & $60-69$ & 1 & 5 \\
\hline 4. & K & $50-59$ & 0 & 0 \\
\hline 5. & SK & $<50$ & 1 & 5 \\
\hline & Jml. & & 20 & 100 \\
\hline
\end{tabular}

Keterangan.

Kat: kategori S. : skor F. : Frekuensi

SB : sangat baik

B : baik

C : cukup

$\mathrm{K}$ : kurang

SK : sangat kurang

Berdasarkan tabel hasil keseluruhan pada siklus II, diperoleh rata-rata 79,85 yang secara klasikal berkategori baik.

Berdasarkan tabel di atas, diketahui bahwa kemampuan siswa kelas VIII B SMP Mutiara setelah mendapatkan tindakan pada siklus II dari 20 orang siswa adalah terdapat 8 orang siswa atau $40 \%$ memperoleh kategori sangat baik, 10 orang siswa atau $50 \%$ memperoleh kategori baik (9 orang siswa tergolong tuntas dan 1 orang tergolong tidak tuntas), 1 orang siswa atau 5\% memperoleh kategori cukup 9 (tergolong tidak tuntas) dan 1 orang atau $5 \%$ siswa memeroleh kategori sangat kurang (tergolong tidak tuntas dikarenakan tidak hadir selama pembelajaran). Secara klasikal, ketuntasan siswa mencapai $85 \%$. Hal ini berarti, siswa kelas VIII B SMP Mutiara Singaraja dapat dikatakan memenuhi syarat ketuntasan yang ditetapkan, yaitu $75 \%$.

Pada siklus I, skor rata-rata siswa adalah 69,05 sementara pada siklus II adalah 79,85 . Hal ini berarti skor rata-rata kemampuan membaca siswa dalam memahami novel remaja dengan menerapkan pendekatan reader respons mengalami peningkatan sebesar 10,8.

Berdasarkan hasil respons siswa pada siklus II, dapat dirinci dari 20 orang siswa yang telah mengisi angket, terdapat 15 orang siswa $(75 \%)$ yang memberikan respons sangat positif terhadap penerapan pendekatan reader respons untuk meningkatkan kemampuan membaca siswa dalam memahami novel 3600 Detik. Sisanya, terdapat 4 orang siswa (20\%) memberikan respons positif dan 1 orang siswa $(5 \%)$ tidak memberikan respons dikarenakan tidak hadir dalam pembelajaran. Dari 20 orang siswa di kelas VIII B SMP Mutiara Singaraja, tidak ada siswa yang memberikan respons yang cukup positif, kurang positif ataupun sangat 
kurang positif. Secara keseluruhan, ratarata data respons yang diperoleh pada pelaksanaan siklus II mencapai 44,65 (tergolong positif).

Kemudian, yang dilakukan oleh peneliti bersama guru pada akhir siklus II adalah menunjukkan bahwa pelaksanaan pembelajaran memahami novel remaja dengan menerapkan pendekatan reader respons secara umum telah berjalan sesuai dengan rencana. Hasil catatan lapangan dan tes kemampuan membaca siswa menunjukkan bahwa indikator keberhasilan penelitian ini telah tercapai sehingga tindakan dihentikan.

Ada beberapa temuan penting yang dibahas pada bagian ini. Pertama, langkahlangkah penerapan pendekatan reader respons dalam proses pembelajaran. Kedua, penerapan pendekatan reader respons dapat meningkatkan kemampuan membaca siswa dalam memahami novel remaja. Ketiga, respons positif siswa dalam pembelajaran memahami novel remaja dengan menerapkan pendekatan reader respons. Terhadap temuan tersebut dapat dijelaskan sebagai berikut.

Temuan pertama, dalam proses pembelajaran terdapat beberapa langkah efektif yang ditempuh untuk memahami novel remaja berdasarkan penerapan pendekatan reader respons. Langkahlangkah tersebut diberikan secara bertahap agar siswa mampu memeroleh pemahaman yang utuh. Setiap langkah yang diberikan kepada siswa juga memiliki perannya masing-masning yang menjadi kesatuan utuh bagi siswa. Dalam pengimplementasiannya, novel yang diberikan kepada siswa adalah novel yang sesuai dengan kondisi lingkungan atau pun kesesuaian kompetensi dasar yang dipelajari, yaitu novel remaja dengan judul 3600 Detik.

Dalam menerapkan pendekatan ini, sangatlah dibutuhkan konsentrasi yang baik bagi siswa. Konsentrasi siswa dalam hal ini dapat diamati melalui fokus pandangan yang diberikan selama mengikuti pembelajaran.

Dimulai dari cara membaca dengan mengikutsertakan emosi yang baik, dalam hal ini tentu konsentrasi sangat perlu agar siswa sendiri mampu merasakan apa yang dilakukan oleh setiap tokohnya, sebabakibat tokoh melakukan sebuah tindakan, dan mengetahui alurnya dengan baik. Tidak hanya itu saja, melalui konsentrasi nantinya siswa akan mampu menjelaskan atau menyampaikan informasi-informasi yang terkandung dalam novel yang telah dibaca.

Kedua, dalam pembelajaran memahami novel remaja dengan menerapkan pendekatan reader respons terlihat pada pencapaian skor pada saat dilaksanakannya pratindakan, tindakan siklus I, dan tindakan siklus II bahwa setiap tindakan telah mengalami peningkatan. Nilai rata-rata pratindakan adalah 60,70, nilai rata-ratapada tindakan siklus I adalah 69,05 , dan nilai rata-rata pada tindakan siklus II adalah 79,05. Jadi, dalam tindakan siklus II lebih dari $75 \%$ dari jumlah siswa mengalami peningkatan sesuai dengan KKM yang sudah ditentukan yaitu 75 . Peningkatan tersebut terjadi karena adanya pembaharuan di dalam proses pembelajaran yang membuat siswa lebih aktif belajar.

Penerapan pendekatan reader respons sangat tepat diterapkan dalam pembelajaran memahami novel remaja. Penerapan pendekatan ini juga dapat membantu meningkatkan pemahaman siswa dalam membaca, khususnya novel. $\mathrm{Hal}$ ini sejalan dengan pernyataan Sarumpaet (2010) yang menyatakan bahwa pendekatan reader respons bertujuan untuk meningkatkan keterampilan pembacanya dalam bergaul dengan sastra. Dengan kata lain, dalam pendekatan ini pembaca berfungsi sebagai penanggap yang secara sukarela mendekati sebuah teks sastra seperti novel salah satunya.

Temuan penelitian di atas juga sejalan dengan hasil penelitian yang dilakukan oleh Inderawati (2009) yang menunjukkan bahwa rata-rata hasil yang diperoleh dalam penelitian ini adalah tercapainya ketuntasan hasil belajar menulis siswa akibat diterapkannya model pembelajaran respons pembaca. Hal tersebut dibuktikan dari hasil penelitian yang menunjukkan bahwa kemampuan menulis siswa kelas eksperimen meningkat secara signifikan dari garis dasar 57,50 pada tes awal 
menjadi 73,98 pada tes pos dan kemampuan berbicara mereka meningkat dari skor 3,4 menjadi 74,4 setelah tindakan.

Temuan ketiga, yaitu siswa memberikan respons yang positif terhadap penerapan pendekatan reader respons dalam meningkatkan kemampuan membaca siswa dalam memahami novel remaja. Secara umum penerapan pendekatan reader respons membuat siswa lebih mudah dan lebih termotivasi untuk mengikuti pembelajaran membaca, khususnya membaca dalam memahami novel remaja. Hal tersebut dapat dilihat dari nilai rata-rata respons yang diberikan oleh siswa dalam pembelajaran. Sebagian besar siswa memberikan respons yang positif terhadap tindakan yang dilakukan selama proses pembelajaran. Pada siklus I, nilai rata-rata respons siswa adalah 43,05, kemudian nilai rata-rata respons siswa meningkat menjadi 44,85 pada siklus II.

Temuan di atas sejalan dengan penelitian yang dilakukan oleh Susilo dan Anisa (2017) dengan judul "Penerapan Model Respon Pembaca dalam Pembelajaran Apresiasi Cerpen di SMA". Dalam penelitiannya secara umum siswa memberikan respons yang sangat positif dengan penerapan pendekatan reader respons dalam pembelajaran. Siswa merasa lebih mudah untuk melakukan sebuah apresiasi berupa tanggapan terhadap sebuah cerpen yang dibacanya.

Selain itu, dari pihak guru bidang studi Bahasa Indonesia SMP Mutiara Singaraja juga memberikan tanggapan yang positif pula terhadap pelaksanaan pembelajaran membaca novel remaja dengan menerapkan pendekatan reader respons. Guru menyatakan persetujuannya bahwa pembelajaran membaca dengan menerapkan pendekatan raeder respons sangatlah baik dan berpeluang besar untuk diterapkan sebagai salah satu alternatif pembelajaran di sekolah, khususnya di SMP Mutiara Singaraja.

Penelitian ini hanya dibatasi dengan penerapan pendekatan reader respons dalam pembelajaran membaca saja. Akan tetapi, tentu diketahuibahwa berbicara, menulis, dan menyimak merupakan catur tunggal yang tak bisa dipisahkan dan sangat berkaitan satu sama lain. Hal itu sejalan dengan apa yang dikatakan oleh Tarigan (1994) setiap keterampilan berbahasa itu erat sekali berhubungan dengan ketiga keterampilan lainnya dengan cara yang beraneka ragam. Keempat keterampilan itu pada dasarnya merupakan satu kesatuan atau caturtunggal. Itu berarti, tidak menutup kemungkinan penggunaan pendekatan reader respons ini juga dapat diterapkan pada salah satu keterampilan yang lainnya selain keterampilan membaca bagi peneliti lain untuk dijadikan sebagai bahan penelitian.

\section{SIMPULAN DAN SARAN}

Ada beberapa hal yang menjadi simpulan dalam penelitian ini. Pertama, dalam menerapkan pendekatan reader respons untuk meningkatkan kemampuan membaca siswa dalam memahami novel remaja, terdapat beberapa langkah pembelajaran yang efektif. Langkahlangkah penerapan pendekatan reader respons dapat meningkatkan kemampuan membaca novel siswa kelas VIII B SMP Mutiara Singaraja sebagai berikut. (1) guru memberikan umpan balik kepada siswa untuk mengetahui kesulitan siswa. (2) guru memberikan penjelasan secara rinci dan jelas mengenai materi pembelajaran membaca novel remaja. (3) guru memberikan pembelajaran kepada siswa dengan menerapakan pendekatan reader respons dalam proses membentuk pemahamannya terhadap novel. Guru membimbing siswa secara intensif sesuai dengan taraf kemampuan masing-masing siswa. (4) guru mengukur kemampuan siswa dengan memberikan tes evaluasi untuk mengukur tingkat pemahaman membaca siswa terhadap novel remaja.

Kedua, pendekatan reader respons dapat meningkatkan kemampuan membaca siswa dalam memahami novel remaja di kelas VIII B SMP Mutiara Singaraja. Hal ini, dapat dilihat dari hasil belajar siswa. Nilai rata-rata kemampuan membaca siswa sebelum diberikan perlakuan adalah 60,70. Setelah diberikan tindakan pada siklus I nilai rata-rata siswa menjadi 69,05. Pada siklus II, skor rata-rata siswa adalah 79,85. 
Dilihat dari peningkatan yang telah diperoleh oleh siswa, ditemukan nilai ketuntasan akhir siswa dalam pembelajaran memahami novel remaja, yaitu sebesar $85 \%$ secara klasikal dari 20 orang siswa yang ada.

Ketiga, penerapan pendekatan reader respons dalam pembelajaran memahami novel remaja diterima secara positif oleh siswa. Secara klasikal respons siswa terhadap penerapan pendekatan reader respons dalam pembelajaran memahami novel remaja pada siklus I, yaitu 43,05 dan pada siklus II meningkat menjadi 44,85. Sikap positif siswa terhadap penerapan pendekatan reader respons menggambarkan bahwa pembelajaran ini dapat dijadikan cara yang disukai siswa sehingga guru memiliki modal yang berharga karena modal belajar ini telah menciptakan lingkungan belajar yang efektif.

Berdasarkan temuan-temuan dalam penelitian ini, peneliti menyampaikan beberapa saran, yaitu (1) guru disarankan agar dapat menerapkan pendekatan reader respons dalam pembelajaran, (2) dari pihak sekolah hendaknya memberikan dukungan terhadap guru untuk menerapkan pendekatan reader respons dalam pembelajaran yang berkaitan dengan proses membaca teks sastra. (3) penelitian ini dapat dijadikan sebagai acuan, pedoman, serta bahan perbandingan untuk menambah wawasan penelitian tentang keefektifan pendekatan reader respons dalam kegiatan pembelajaran membaca, khususnya memahami novel remaja.

\section{DAFTAR PUSTAKA}

Astika, I Made dan I Nyoman Yasa. 2014. Sastra Lisan, Teori dan Penerapannya. Yogyakarta: Graha IImu.

Hardjana, Andre. 1991. Kritik Sastra: Sebuah Pengantar. Jakarta: PT. Gramedia.
Indrawati, Rita. 2009. Model Pembelajaran Berbasis Respons Pembaca dan Simbol Visual untuk Mengembangkan Apresiasi Sastra dan Kemampuan Berbahasa Inggris Mahasiswa. Tersedia pada, http://eprints.unsri.ac.id/2735/1/Rita I nderawati Model Pembelajaran Ber basis Respons Pembaca dan Simb ol Visual.pdf (diakses tanggal 10 November 2017).

Priyatni, Endah Tri. 2012. Membaca Sastra dengan Ancangan Literasi Kritis. Jakarta: Bumi Aksara.

Ratna, Nyoman Kutha. 2004. Teori, Metode, dan Teknik Penelitian Sastra. Denpasar: Pustaka Pelajar.

Sarumpaet, Riris K. Toha. 2010. Pedoman Penelitian Sastra Anak. Jakarta: Pusat Bahasa Kementerian Pendidikan Nasional 2010.

Sudiana, I Nyoman. 2007. Membaca. Malang: Universitas Negeri Malang.

Sujanto, J. Ch. 1988. Keterampilan Berbahasa Membaca-MenulisBerbicara untuk Mata Kuliah Dasar Umum Bahasa Indonesia. FKIPUNCEN Jayapura.

Susilo, Jimat dan Aan Anisa. 2017. "Penerapan Model Respon Pembaca dalam Pembelajaran Apresiasi Cerpen di SMA". Tugas Akhir (tidak diterbitkan). Universitas Swadaya Gunung Jati Cirebon.

Tarigan, Henry Guntur. 1979. Membaca sebagai Suatu Keterampilan Berbahasa. Bandung: Angkasa Bandung.

Tarigan, Henry Guntur. 1994. Menulis sebagai suatu Keterampilan Berbahasa. Bandung: Angkasa.

Yamin, Moh. 2014. Teori dan Metode Pembelajaran (Konsepsi, Strategi dan Praktik Belajar yang Membangun Karakter). Malang: Madani. 